\title{
Are Unprecedented Monetary Policy Effective: Recent Japanese Case
}

\author{
Yutaka Kurihara \\ Correspondence: Yutaka Kurihara, Departmentof Economics, Aichi University, 4-60-6 Hiraike, Nakamura, Nagoya, \\ Aichi, 453-8777, Japan.
}

Received: March 29, 2018

doi:10.11114/aef.v5i3.3222

\author{
Accepted: April 16, 2018 \\ Available online: April 19, 2018 \\ URL: https://doi.org/10.11114/aef.v5i3.3222
}

\begin{abstract}
This paper empirically analyzes the recent monetary policy in Japan with the era of Abenomics as the focus. Serious deflation damaged the Japanese economy and unprecedented monetary policy has been conducted to combat deflation. Stock prices have risen since the conduction of this unprecedented policy and low unemployment has been attained, but the effectiveness of the policy needs to be explored. This paper examines this problem from the view of inflation and GDP. Revised version of $\mathrm{P}^{*}$ model is employed for empirical analyses. Empirical results indicate that monetary policy has been effective in recovering the economy (GDP), but there is no significant relationship between monetary expansion and inflation rate. To promote more monetary expansion is one choice, but there would be some side effects on the economy.
\end{abstract}

Keywords: deflation, GDP, inflation, Japan, monetary policy, P* model

\section{Introduction}

The Japanese economy enjoyed high economic growth in the 1980s. Stock and land prices increased tremendously. However, since the burst of the bubble economy at the beginning of the 1990s, serious deflation has hit Japanese economy. Under such situations, the Japanese central bank, Bank of Japan (BOJ) has conducted unprecedented monetary policy to combat deflation. This paper analyzes the recent monetary policy in Japan. The effectiveness of the policy is examined from the view of inflation and GDP.

This paper focuses on inflation and GDP. The idea is borrowed from economic theories. The most typical and recent one is the Taylor rule. The Taylor rule assumes that central banks focus on inflation and output when setting monetary policy (see, e.g., Taylor, 1993). The Taylor rule has been used in many cases, both in academic ones and real-world scenarios, as this rule is applicable in many ways, sometimes quite clearly and easily. This rule entails both simplicity and realistic appropriations.

Monetary policy has been discussed, and, recently, many researchers have noted that monetary policy should be conducted systematically. The reason why monetary policy instead of fiscal policy has been given attention is that many countries have accumulated huge debt and the governments cannot expand fiscal expenditures easily. The conduct of monetary policy based on the rules is believed to stabilize economy given the maintenance of transparency and credibility which many central banks would like to keep on. The $\mathrm{k} \%$ rule (money stock), the exchange rate control rule, and the nominal growth rate rule policy, have received much attention in literature; however, the Taylor rule has been used and been discussed thoroughly.

This policy rule, Taylor rule, has been changed and applied to empirical analyses and to theoretical models in many forms. Also, the policy rule has been examined for the cases of the United States, the Euro area, and developed countries as well as many newly industrialized and developing economies. However, few studies have been examined for the case of Japan and other nations. The reason may be that the introduction of the low or zero interest rate policy has been introduced. Japan is not introducing a minus interest rate policy. In some countries, especially some developed economies, there appears to be some need for an augmented Taylor rule as this issue is strongly related with monetary policy rules. For such examples, central banks would stabilize price level (Svensson, 2003) and nominal income (Bean, 1983; Sumner, 1989; Woodford, 2012). Like these, the discussion of monetary policy rules is not a new issue but it has been discussed all over the world.

The rules employed in this paper are surely related to the Taylor rule $(1979,1993)$. The original Taylor rule sets the federal funds rate of the United States. Wang, Morlev, and Ordonez (2016) found that effects of asset prices on the 
Taylor rule change owing to the country and the form that wealth adopts. Bauer \& Neuenkirch (2017) showed that the Bank of England and the European Central Bank have a significantly negative reaction to the uncertainty of inflation forecasting. Chen \& Kashiwagi (2017) indicated relatively flat coefficients of inflation and insignificant coefficients of the output gap for recent Japanese cases. Drager \& Lamla (2017) found that disagreement is significantly by central bank transparency as well as some kinds of news on money and credit conditions.

However, it should be noted that interest rates in Japan have been almost zero. Introducing the Taylor rule causes some problems. Traditional economic theory is sometimes not applicable. Additionally, instead of manipulating interest rates, aggressive monetary expansion has been conducted. Some of the discussion about monetary policy rules has turned into unconventional tools that might allow monetary policy to escape this liquidity trap. It would be worth re-examining whether or not the quantity of money can serve as an important policy lever. In other words, including interest rates for analyses sometimes causes serious problems. Application of theoretical models for monetary policy rules to the real world sometimes needs careful attention.

Also, there is another issue to be taken into consideration. Recently, in Abenomics, which is named after the prime minister of Japan), the target of inflation has been provided in reality. It makes sense to set such targeting as many countries have adopted inflation targeting as a monetary policy. There are a lot of discussions, but there is no consensus about this policy and its appropriateness. Fukuda (2015) analyzed the stock prices rising, and foreign investors were aggressive in purchasing Japanese stocks. Hausman \& Wieland (2015) indicated that the response of exports to the weak yen is not large, and there is little evidence that expansionary monetary policy has large effects on domestic consumption. De Anrea \& Iacoviello (2016) showed that Japan has made some progress towards combating deflation, but many more measures are necessary to make the inflation rate two percent in a stable condition. The two percent has been repeatedly advocated by the BOJ. Kurihara (2016) indicated that Japanese interest rates, U.S. interest rates, and the exchange rate of yen/USD have effects on Japanese stock prices. Morita (2017) showed that Abenomics found that anticipated fiscal policy shock positively contributes to consumption dynamics. Michaelis \& Wazka (2017) found that, during Abenomics, responses of the price level to the policy (Abenomics) are greater than those of real GDP. Like these, examining recent monetary policy in Japan, Abenomics which has been conducted from 2003 should be considered. This paper focuses comparing the Abenomics era with other periods in Japan.

\section{Model for Empirical Analyses}

\subsection{Japanese Experience}

In February 1999, the BOJ adopted the zero interest rate policy, which was unprecedented all over the world, to overcome deflation and to recover the economy. In August 2000, as the economic situation displayed bright signs of recovery, the situation had not changed greatly. The BOJ introduced a new monetary policy called the quantitative easing policy in 2001. The quantitative easing policy dates back to March 9, 2001. This policy received much attention from all over the world as it was unprecedented at that time. Under this unconventional policy, the BOJ bought a large sum of Japanese government bonds as the main instrument to reach its operating target of current account balances held by financial institutions at the BOJ. Most purchases were and have been conducted by Japanese residents including financial institutions, so the demand or price has been stable.

In March 2006, the BOJ quit quantitative easing policy under signs that deflation was ending. In July 2006, the zero interest rate policy, which had been conducted in March 2001, ended. After the occurrence of the subprime problems in 2007 and the Lehman shock in 2008, a huge amount of money has flowed into the Japanese financial markets in spite of the fact that the Japanese economy has not enjoyed good situation for about 20 years. In Yen-carrying trading, borrowing yen (low interest rates) and investing by other currencies was conducted largely as the Japanese interest rate was quite low. The Japanese yen appreciated largely against other currencies, which hit the Japanese economy as yen's appreciation led to deteriorating exports. Japanese stock prices decreased sharply. Following this global financial crisis, the BOJ increased the amount of its Japanese government bond purchases and implement unconventional some measures to boost the economy. It was expected to achieve financial stability.

In October 2010, the BOJ introduced its comprehensive monetary easing policy to respond to the re-emergence of deflation. One key measure was an asset purchase program that involved government bonds as well as private assets, which was also unprecedented. The Japanese government also conducted more aggressive fiscal policy. The zero interest rate policy was in effect from October 2010 and layer minus interest policy is conducted and the policy continues.

A drastic new policy called Abenomics was adopted in April 2013 to overcome deflation. Japan has been under severe economic conditions (i.e., deflation). By strengthening coordination between the BOJ and the government, the Japanese government has conducted measures to achieve a new fiscal structure to ensure the credibility of the fiscal condition. At that time, the BOJ introduced an unprecedented and unconventional aggressive monetary policy that expands the 
volume of government bond purchases to flow capital into markets for consumption, investment, and so on. In short, Abenomics combines monetary policy and fiscal policy as well as growth reforms. As a result of this policy, exchange rates depreciated, and stock prices rose tremendously.

As explained, the Japanese economy experienced zero or low interest rates around 2000. Also, it should be noted that more aggressive monetary policy has been conducted since the 2010s. Drastic measures called Abenomics began in 2013. These situations are considered, and empirical analyses to evaluate such policies are performed in this paper below.

\subsection{Basic Framework}

The basic framework employed in this paper can be said that its baseline is the P-star $\left(\mathrm{P}^{*}\right)$ model (Hallman, Porter, \& Small, 1991); Orphanides \& Porter, 2000; Belongia \& Ireland, 2017. The typical form is the equation (1):

$$
\mathrm{PtYt}=\mathrm{MtVt}
$$

Pt is the price level at time t, and Yt is the real GDP. Mt is money stock, and Vt is the velocity of money. After rearranging the equation (1) and replacing velocity with the same low-frequency trend, $\mathrm{Vt}$, and $\mathrm{Yt}$ is replaced by its potential variable, the equation (2) can be set.

$$
\operatorname{Pt}(\text { new })=\operatorname{MtVt}(\text { new }) / Y t(\text { new })
$$

In the equation, (new) denotes convergence level. The equation (2) means that $\mathrm{Pt}$ moves to $\mathrm{Pt}(\mathrm{new})$ towards which the actual price level Pt will gradually converge. The important point is to calculate an estimate of the associated price gap $(\mathrm{Pt}(\mathrm{new})-\mathrm{Pt})$, which is defined as the difference between the logarithms of the two price series.

Also, nominal income can be expressed as follows in equation (3).

$$
\mathrm{Yt}=\mathrm{MtVt}
$$

where $\mathrm{Yt}$ denotes nominal income. With the trend value of velocity, $\mathrm{Vt}(\mathrm{new})$, the target value for nominal income, Yt(new), can be expressed by:

$$
\mathrm{Yt}(\text { new })=\operatorname{MtVt}(\text { new })
$$

In equations (3) and (4), for a given level of the money stock, Mt, Yt(new) is the value to which actual nominal income, $\mathrm{Xt}$, converges as velocity gradually returns to its long-run value. $\mathrm{Vt}(\mathrm{new})$. The proxy makes it possible to calculate an estimate of the associated income gap (Yt(new) - Yt), which is defined as the difference between the logarithms of the two series. This is basically the same with equations (3) and (4) and the concept of the P-star model.

\subsection{Empirical Estimations}

The hypotheses based on this model (see, Belongia \& Ireland, 2017) is that whenever money stock becomes a target for price level and a target for nominal income through (2) and (4), the growth rate of the gap will change to close the gap. The estimated equations are the same with Hallman et al. (1991) and Belongia and Ireland (2017).

$$
\Delta^{2} \mathrm{Pt}=\alpha+\beta 1 \Delta^{2} \mathrm{Pt}-1+\beta 2 \Delta^{2} \mathrm{Pt}-2+\beta 3 \Delta^{2} \mathrm{Pt}-3+\beta 4 \Delta^{2} \mathrm{Pt}-4+\gamma(\mathrm{Pt}-1(\text { new })-\mathrm{Pt}-1)+\varepsilon t
$$

where $\Delta^{2} \mathrm{Pt}$ is the change in inflation rate and (Pt-1(new) - Pt-1) is the lag of the price gap defined above in this paper. In terms of this regression, the null hypothesis is whether the coefficient on the lagged price is less than or equal to zero, and the alternative hypothesis is that the coefficient is strictly positive.

Also, for the case of nominal income, the equation (6) is estimated.

$$
\Delta^{2} \mathrm{Yt}=\alpha+\beta 1 \Delta^{2} \mathrm{Yt}-1+\beta 2 \Delta^{2} \mathrm{Yt}-2+\beta 3 \Delta^{2} \mathrm{Yt}-3+\beta 4 \Delta^{2} \mathrm{Yt}-4+\gamma(\mathrm{Yt}-1(\mathrm{new})-\mathrm{Yt}-1)+\varepsilon \mathrm{t}
$$

Where $\Delta^{2} \mathrm{Yt}$ is the change in inflation rate and (Y-1(new) - Y-1) is the lag of the nominal income gap defined as equation (5). In terms of this regression, too, the null hypothesis is determine if the coefficient on the lagged nominal income gap is less than or equal to zero, and the alternative hypothesis is that the coefficient is strictly positive. $\gamma$ is the most important coefficient to be checked.

For the methods of regression analysis, along with ordinary least squares (OLS), Robust estimation is used for estimation. Robust estimation is unlike maximum likelihood estimation. OLS estimates for regression are sensitive to the observations that do not follow the pattern of the other observations. This is not a problem if the outlier is an extreme observation from the tail of a normal distribution. However, if the outlier is from non-normal measurement error or some other violation of standard OLS, it compromises the validity of the regression results if a non-robust regression method is employed. In this analysis, the sample is not so large, especially for the case of Abenomics era, so Robust estimation is employed along with OLS.

\section{Data and Empirical Results}

All of the data are from the International Financial Statistics (IMF). For the price, the consumer price index is employed. 
The sample period is 2000Q1-2017Q1, 2000Q1-2009Q4, 2010Q1-2017Q1, 2013Q1-2017Q1, and 2013Q1-2017Q1. The divisions were explained in the previous section, and the data are quarterly.

The results are shown in Table 1 to Table 4. Some columns in these tables are empty because of no singular matrix. For the inflation rate, target is set on two percent as explained in section 1. In the case of GDP growth, three percent is employed. The reason is not so robust, but the Japanese government states that 'By generally mobilizing all measures and pushing up the robust wage increases and investment, the government will endeavor to ensure the exit from deflation and aim to realize the nominal GDP of 600 trillion yen' on December 8, 2017 (Cabinet office). Attaining this goal seems difficult, but high economic growth is surely necessary. From the start of Abenomics in 2013, the Japanese nominal GDP growth rate has been one to two percent, so three percent is used for this analysis.

Table 1. Price difference: OLS

\begin{tabular}{|c|c|c|c|c|c|}
\hline Sample period & 2000Q1 2017Q1 & 2000Q1 2009Q4 & 2010Q1 2017Q1 & 2013Q1 2017Q1 & 2013Q1 2017Q1 \\
\hline \multirow[t]{2}{*}{$\mathrm{C}$} & $0.1009^{*}$ & $0.1774 * *$ & 0.0213 & $0.5971 * *$ & \\
\hline & $(1.8771)$ & $(2.0667)$ & $(0.3102)$ & $(2.5979)$ & \\
\hline \multirow[t]{2}{*}{ Price(-1) } & $0.9446^{* * *}$ & $0.8379 * * *$ & $0.9990 * * *$ & $0.7763 * * *$ & \\
\hline & (11.5144) & $(7.6389)$ & $(8.0165)$ & $(3.3434)$ & \\
\hline \multirow[t]{2}{*}{ Price(-2) } & -0.0464 & 0.0572 & -0.1840 & -0.0631 & $0.8370^{*}$ \\
\hline & $(-0.4063)$ & $(0.3948)$ & $(-0.1020)$ & $(-0.1978)$ & (2.0339) \\
\hline \multirow[t]{2}{*}{ Price(-3) } & 0.1631 & 0.1870 & 0.1778 & 0.3403 & 0.2052 \\
\hline & $(1.4229)$ & $(1.2929)$ & $(0.9750)$ & (1.0540) & $(0.7389)$ \\
\hline \multirow[t]{2}{*}{ Price(-4) } & $-0.2127 * * *$ & $-0.2445^{* *}$ & $-0.2938 * *$ & $-0.6124 * *$ & -0.4224 \\
\hline & $(-2.7641)$ & $(-2.4526)$ & $(-2.3310)$ & $(-2.5983)$ & $(-0.8494)$ \\
\hline $2 \%$-price(-1) & & & & & $\begin{array}{c}-0.1662 \\
(-0.5885)\end{array}$ \\
\hline $\operatorname{Adj} . R^{2}$ & 0.8575 & 0.8627 & 0.7368 & 0.7420 & 0.3179 \\
\hline F-statistic & 217.7765 & 126.7501 & 45.1024 & 11.7899 & \\
\hline Prob & 0.0000 & 0.0000 & 0.0000 & 0.0005 & \\
\hline \multicolumn{6}{|l|}{ (F-statistic) } \\
\hline D.W. & 1.8243 & 1.8322 & 1.7444 & 2.1370 & 0.8379 \\
\hline
\end{tabular}

Note: Parentheses are t-statistics. $* *, * *$, and $*$ denote significance at $1,5,10 \%$ level.

Table 2. Price difference: Robust Least Squares

\begin{tabular}{|c|c|c|c|c|}
\hline Sample period & 2000Q1 2017Q1 & 2000Q1 2009Q4 & 2010Q1 2017Q1 & 2013Q1 2017Q1 \\
\hline $\mathrm{C}$ & $\begin{array}{c}0.0742 \\
(1.4556)\end{array}$ & $\begin{array}{c}0.1350 \\
(1.5771)\end{array}$ & $\begin{array}{c}-0.0133 \\
(-0.2060)\end{array}$ & \\
\hline Price(-1) & $\begin{array}{c}0.9371 * * * \\
(12.0499)\end{array}$ & $\begin{array}{c}0.8413 * * * \\
(7.6911)\end{array}$ & $\begin{array}{c}0.9863 * * * \\
(8.4496)\end{array}$ & \\
\hline Price(-2) & $\begin{array}{c}-0.0646 \\
(-0.5969)\end{array}$ & $\begin{array}{c}0.0495 \\
(0.3450)\end{array}$ & $\begin{array}{c}-0.2126 \\
(-1.2589)\end{array}$ & $\begin{array}{l}0.8278^{*} \\
(1.9362)\end{array}$ \\
\hline Price(-3) & $\begin{array}{c}0.1434 \\
(1.3197)\end{array}$ & $\begin{array}{c}0.1788 \\
(1.2401)\end{array}$ & $\begin{array}{c}0.1122 \\
(0.6568)\end{array}$ & $\begin{array}{c}0.1776 \\
(0.2863)\end{array}$ \\
\hline Price(-4) & $\begin{array}{c}-0.1629 * * \\
(-2.2324)\end{array}$ & $\begin{array}{c}-0.2228 * * \\
(-2.2405)\end{array}$ & $\begin{array}{c}-0.1908 \\
(-1.6163)\end{array}$ & $\begin{array}{l}-0.4185 \\
(0.4178)\end{array}$ \\
\hline $2 \%$-price(-1) & & & & $\begin{array}{c}-0.1325 \\
(-0.4516)\end{array}$ \\
\hline Adj.Rw $w^{2}$ & 0.8951 & 0.9113 & 0.7917 & 0.5084 \\
\hline Rn-squared statistic & 967.3297 & 519.6275 & 184.9999 & 16.6083 \\
\hline $\begin{array}{l}\text { Prob } \\
\text { (Rn-squared statistic) }\end{array}$ & 0.0000 & 0.0000 & 0.0000 & 0.0023 \\
\hline Schwarz criterion & 146.2698 & 116.9632 & 67.5629 & 18.0273 \\
\hline
\end{tabular}

Note: Parentheses are z-statistics. **, **, and * denote significance at $1,5,10 \%$ level. 
Table 3. GDP difference: OLS

\begin{tabular}{|c|c|c|c|c|c|}
\hline Sample period & 2000Q1 2017Q1 & 2000Q1 2009Q4 & 2010Q1 2017Q1 & 2013Q1 2017Q1 & 2013Q1 2017Q1 \\
\hline $\mathrm{C}$ & $\begin{array}{l}0.2453^{*} \\
(1.6709)\end{array}$ & $\begin{array}{l}0.5064 * \\
(1.9385)\end{array}$ & $\begin{array}{c}0.0406 \\
(0.2396)\end{array}$ & $\begin{array}{l}1.6514 * * \\
(2.6033)\end{array}$ & \\
\hline GDP(-1) & $\begin{array}{c}0.8688 * * * \\
(10.4612)\end{array}$ & $\begin{array}{c}0.7076^{* * * *} \\
(6.5873)\end{array}$ & $\begin{array}{c}0.9567 * * * \\
(7.3456)\end{array}$ & $\begin{array}{l}0.6153 * \\
(1.9397)\end{array}$ & \\
\hline GDP(-2) & $\begin{array}{c}0.1124 \\
(1.0121)\end{array}$ & $\begin{array}{l}0.1516^{*} \\
(1.8592)\end{array}$ & $\begin{array}{c}-0.0336 \\
(-0.1896)\end{array}$ & $\begin{array}{c}-0.1830 \\
(-0.4937)\end{array}$ & $\begin{array}{l}0.8146^{*} \\
(2.2337)\end{array}$ \\
\hline GDP(-3) & $\begin{array}{c}-0.0245 \\
(-0.2215)\end{array}$ & $\begin{array}{c}0.1516 \\
(1.1365)\end{array}$ & $\begin{array}{c}-0.2504 \\
(-0.1410)\end{array}$ & $\begin{array}{c}-0.1181 \\
(-0.3489)\end{array}$ & $\begin{array}{c}-0.1425 \\
(-0.2622)\end{array}$ \\
\hline $\operatorname{GDP}(-4)$ & $\begin{array}{c}-0.0894 \\
(-1.0966)\end{array}$ & $\begin{array}{c}-0.2459 * * \\
(-2.4629)\end{array}$ & $\begin{array}{c}0.0120 \\
(0.0922)\end{array}$ & $\begin{array}{c}-0.1171 \\
(-0.4621)\end{array}$ & $\begin{array}{c}0.5105 \\
(1.6354)\end{array}$ \\
\hline $3 \%-G D P(-1)$ & & & & & $\begin{array}{r}-0.8799 * * \\
(-2.7387)\end{array}$ \\
\hline Adj. $R^{2}$ & 0.8225 & 0.8066 & 0.6635 & 0.3243 & 0.1311 \\
\hline F-statistic & 167.8770 & 84.4634 & 32.0615 & 2.7999 & \\
\hline $\begin{array}{l}\text { Prob } \\
\text { (F-statistic) }\end{array}$ & 0.0000 & 0.0000 & 0.0000 & 0.0793 & \\
\hline D.W. & 1.8947 & 1.8007 & 2.0071 & 1.4508 & 0.8964 \\
\hline
\end{tabular}

Note: Parentheses are t-statistics. **,**, and * denote significance at 1, 5, 10\% level.

Table 4. GDP difference: Robust Least Squares

\begin{tabular}{|c|c|c|c|c|}
\hline Sample period & 2000Q1 2017Q1 & 2000Q1 2009Q4 & 2010Q1 2017Q1 & 2013Q1 2017Q1 \\
\hline $\mathrm{C}$ & $\begin{array}{c}0.2019 \\
(1.5009)\end{array}$ & $\begin{array}{l}0.4500^{*} \\
(1.7516)\end{array}$ & $\begin{array}{c}0.0467 \\
(0.3444)\end{array}$ & \\
\hline $3 \%-G D P(-1)$ & $\begin{array}{c}0.8586^{* * * *} \\
(11.2859)\end{array}$ & $\begin{array}{c}0.7324 * * * \\
(6.9329)\end{array}$ & $\begin{array}{c}0.9124 * * * \\
(8.7678)\end{array}$ & $\begin{array}{c}-0.9253 * * * \\
(-2.6838)\end{array}$ \\
\hline GDP(-2) & $\begin{array}{c}0.0521 \\
(0.5123)\end{array}$ & $\begin{array}{c}0.1615 \\
(1.2259)\end{array}$ & $\begin{array}{c}0.0216 \\
(0.1526)\end{array}$ & $\begin{array}{c}0.8365 * * \\
(2.1374)\end{array}$ \\
\hline GDP(-3) & $\begin{array}{l}-0.0020 \\
(0.9838)\end{array}$ & $\begin{array}{c}0.2098 \\
(1.5994)\end{array}$ & $\begin{array}{c}-0.3081 * * \\
(-2.1714)\end{array}$ & $\begin{array}{c}-0.1690 \\
(-0.2896)\end{array}$ \\
\hline GDP(-4) & $\begin{array}{c}-0.0443 \\
(-0.5950)\end{array}$ & $\begin{array}{c}-0.2588 * * \\
(-2.4939)\end{array}$ & $\begin{array}{c}0.1507 \\
(1.4475)\end{array}$ & $\begin{array}{c}0.5402 \\
(1.6124)\end{array}$ \\
\hline Adj. $R w^{2}$ & 0.8260 & 0.8572 & 0.8069 & 0.4091 \\
\hline Rn-squared statistic & 1950003 & 344.0798 & 195.7178 & 61.8065 \\
\hline $\begin{array}{l}\text { Prob } \\
\text { (Rn-squared statistic) }\end{array}$ & 0.0000 & 0.0000 & 0.0000 & 0.0000 \\
\hline Schwarz criterion & 80.9187 & 102.1853 & 81.8043 & 19.3399 \\
\hline
\end{tabular}

Note: Parentheses are z-statistics. **, **, and * denote significant at 1, 5, 10\% level.

The results are almost robust, and the empirical analyses are performed in the next section 4 .

\section{Analyses of the Empirical Results}

The empirical results in section 3 indicate that monetary policy has been effective to boost the economy, but there is no significant relationship between monetary expansion and inflation rate. The policy that policy authorities should follow is difficult to judge. One choice is to continue aggressive monetary policy or conduct much more expansion policy. This is a direct answer from the empirical analyses.

Interpreting the empirical results directly tells us that Japan should take this ultra-monetary loosing policy, which is more aggressive than the past. However, in conducting such policies, there is some possibility that serious side effects will occur on the economy. Many countries (e.g., the United States) have begun to conduct exit policy from the aggressive monetary policy. However, the empirical studies conducted in this paper show nothing. There is also such a situation where inflation would not occur in Japan or in other countries. Sticking to the two percent inflation rate itself would contain some problems and be inappropriate. The era of high economic growth has passed from the world. There are only a few countries that experience such as double digit inflation. The appropriateness of the two percent should be examined carefully.

\section{Conclusion}

This paper empirically examined the recent monetary policy in Japan with the era of Abenomics as the focus. Empirical results indicated that monetary policy has been effective to boost the Japanese economy. Surely, the growth rate is gradually increasing, and almost perfect employment has been accomplished. On the other hand, there was no 
significant relationship between unconventional monetary expansion and inflation rate during the era of Abenomics. The empirical results showed that the BOJ should take an ultra-loosing policy more aggressive than the past to raise the inflation rate and combat deflation. However, in conducting such policies, serious side effects on the economy would occur as many economics indicate.

For the GDP, the results are clear and robust. However, there may be some problems. Monetary expansion is not defined clearly. Also, GDP is sometimes renovated. Sometimes market dispersions cause instability or turmoil. Such mechanisms should be examined much more, but few studies have examined the relationship between forecast disparities and macroeconomic uncertainty in the fields of theoretical studies and in empirical fields, despite the importance of this problem.

Furthermore, side effects or the exit policy of aggressive monetary policy should be analyzed much more. This would be one of the most important issues for the conduction of monetary and fiscal policies.

\section{Acknowledgements}

This study is supported by JSPS KAKENHI.

\section{References}

Bauer, C., \& Neuenkirch, M. (2017). Forecast uncertainty and the Taylor rule. Journal of International Money and Finance, 77(C), 99-116. http://doi.10.1016/j.jimonfin.2017.07.017

Bean, C. R. (1983). Targeting nominal income: An appraisal. The Economic Journal, 93, 806-819. https://doi.org/10.2307/2232747

Belongia, M. T., \& Ireland, P. (2017). Circumventing the zero lower bound with monetary policy rules based on money. Journal of Macroeconomics, 54(A), 42-58. https://doi.org/10.1016/j.jmacro.2017.01.007

Cabinet Office. (2017). New economic policy package. Retrieved from http://www5.cao.go.jp/keizai1/package/20171208_package_en.pdf

Chen, J., \& Kashiwagi, M. (2017). The Japanese Taylor rule estimated using censured quantile regressions. Empirical Economics, 52(1), 357-371. https://doi.org/10.1007/s0018

De Anrea, M., \& Iacoviello, M. (2016). Raising an inflation target: The Japanese experience with Abenomics. European Economics Review, 88, 67-87. https://doi.org/10.1016/j.euroecorev.2016.02.021

Drager, L., \& Lamla, M. J. (2017). Explaining disagreement on interest rates in a Taylor-rule setting, Scandinavian Journal of Economics, 119(4), 987-1009. https://doi.org/10.1111/sjoe.12217

Fukuda, S. (2015). Abenomics: Why was it so successful in changing market expectations? Journal of the Japanese and International Economics, 37, 1-20. https://doi.org/10.1016/j.jjie.2015.05.006

Hallman, J. J., Porter, R. D., \& Small, D. H. (1991). Is the price level tied to the M2 monetary aggregate in the long run? American Economic Review, 81, 841-858.

Hausman, J. K. \& Wieland, J. F. (2015). Overcoming the lost decades? Abenomics after three years. Brooking Papers on Economic Activity, 51(2), 385-413. https://doi.org/10.1353/eca.2015.0008

Kurihara, Y. (2016). Effectiveness of the zero interest rate policy for financial markets in Japan: Principle component analysis, Applied Economics and Finance, 3(3), 103-111. https://doi.org/10.11114/aef.v3i3.1532

Michaelis, H., \& Wazka, S. (2017). Are there differences in the effectiveness of quantitative easing at the zero-lower-bound in Japan over time? Journal of International Money and Finance, 70, 204-233. https://doi.org/10.1016/j.jimonfin.2016.08.008

Morita, H. (2017). Effects of anticipated fiscal policy shock on macroeconomic dynamics in Japan. Japanese Economic Review, 68(3), 364-393. https://doi.org/10.1111/jere.12140

Orphanides, A., \& Porter, R. D. (2000). P-star revisited: Money-based inflation forecasts with a changing equilibrium velocity. Journal of Economics and Business, 52, 87-100. https://doi.org/10.1016/S0148-6195(99)00028-4

Sumner, S. (1989). Using futures instrument prices to target nominal income. Bulletin of Economic Research, 41, 157-162. https://doi.org/10.1111/j.1467-8586.1989.tb00287.x

Svensson, L. E. O. (2003). Escaping from a liquidity trap and deflation: The foolproof way and others. Journal of Economic Perspective, 17, 145-166. https://doi.org/10.1257/089533003772034934

Taylor, J. B. (1979). Estimation and control of a macroeconomic model with rational expectations. Econometrica, 47(5), 1267-1286. https://doi.org/10.2307/1911962 
Taylor, J. B. (1993). Discretion versus policy rules in practice. Cambridge-Rochester Conference Series. Public Service, 39, 195-214.

Wang, R., Morlev, B., \& Ordonez, J. (2016). The Taylor rule, wealth effects and the exchange rate. Review of International Economics, 24(2), 282-301. https://doi.org/10.1111/roie.12213

Woodford, M. (2012). Methods of policy accommodation at the lower bound. In: The changing policy landscape. Federal Reserve Bank of Kansas City, 185-288.

\section{Copyrights}

Copyright for this article is retained by the author(s), with first publication rights granted to the journal.

This is an open-access article distributed under the terms and conditions of the Creative Commons Attribution license which permits unrestricted use, distribution, and reproduction in any medium, provided the original work is properly cited. 